\title{
Conscription Systems, Political Survival, and Battlefield Deaths*
}

\author{
Douglas B. Atkinson ${ }^{\dagger}$ \\ Kevin Fahey \\ René Lindstädt ${ }^{\S}$ \\ Zach Warner ${ }^{\text {Il }}$
}

July 8, 2021

\begin{abstract}
How do countries' conscription systems affect their ability to fight wars? Scholars have devoted significant attention to understanding how domestic political concerns influence military strategy, but we do not yet know how these concerns are shaped by military labor policies. We argue that conscription systems determine how the human costs of war are distributed throughout society, and in turn, the government's tolerance for battlefield casualties in pursuit of victory. Using new data on every country's conscription policy from 1800 to the present, we demonstrate that countries with selective conscription experience more casualties than those with universal conscription or volunteer militaries. To examine the mechanism we theorize, we then conduct an in-depth case study of the United States' experience during the Vietnam War. Using a difference-in-differences design and new data on all American deaths in Vietnam, we show that changes in county death rates after the introduction of the lottery reflect electoral considerations.
\end{abstract}

*We thank Rikhil Bhavnani, Brad Gomez, Raymond Hicks, Gary King, Chris Reenock, Rocío Titiunik, Josh Tucker, and seminar participants at the 2019 LDS Scholars Workshop at Brigham Young University, the 2019 and 2021 EPSA annual conferences, and the University of Salzburg for their helpful feedback. The authors are listed in alphabetical order; all authors contributed equally.

$\dagger$ Postdoctoral University Assistant, University of Salzburg. email: douglasb.atkinsond@sbg.ac.at, web: https: //dougbatkinson. wordpress . com/.

${ }^{\ddagger}$ Lecturer, Swansea University. email: K. T.Fahey@Swansea.ac.uk, web: http://www . kevintfahey.com/.

${ }^{\S}$ Professor, University of Birmingham. email: r.lindstaedt@bham.ac.uk, web: https://renelindstaedt. com/.

IIAssistant Professor, Purdue University. email: zachwarner@purdue . edu, web: http: //www . zachwarner . net. 
When the United States intervened in Vietnam, ${ }^{1}$ the majority of its army was made up of conscripts. American soldiers were recruited through a decentralized and selective draft system that had led to victory in the Second World War just ten years earlier. Yet the Vietnam War dragged on and the United States found itself unable to defeat a much weaker opponent (McMahon 2002). Many attributed American struggles to the draft, believing that its disproportionate effect on Black men and the poor was causing morale problems at home and on the battlefield (Appy 1993; Baskir and Strauss 1978; Murray 1971), so in 1969 this system was replaced with a lottery. The American warfare strategy changed immediately and dramatically: troop numbers decreased and the use of air power increased-even though senior officials acknowledged that this strategy was unlikely to lead to victory.

The American experience in Vietnam highlights an important question in the literature on the domestic politics of war: how do military labor acquisition systems impact countries' warfare strategies? Scholars have explored a number of links between domestic politics and the battlefield, particularly the effect of casualties on public opinion (Berinsky 2009; Gartner and Segura 1998; Gelpi, Feaver, and Reifler 2009; Mueller 1973) and the subsequent electoral consequences (Althaus, Bramlett, and Gimpel 2012; Croco 2011; Grose and Oppenheimer 2007). But we know far less about how military recruitment interacts with these better-explored mechanisms tying battlefield casualties to political survival.

In this paper, we argue that conscription systems impact governments' tolerance for casualties by determining their political exposure to the battlefield. Unlike all-volunteer militaries or universal conscription, in which all citizens of legal age are compelled to serve, selective conscription allows governments to target specific subgroups of the population for compulsory service. By giving politicians choice over who is called to serve on the battlefield, selective conscription allows them to shield politically valuable groups (such as swing voters in electoral democracies or elites' coethnics in nondemocracies). These groups remain insulated from the human cost of the war and so are less likely to pull their support for the government, minimizing the risk that the government is replaced

1. The first American casualty of the conflict which would come to be known (in America) as the Vietnam War was recorded on June 8, 1956. 
even when casualties rise. In short, we argue that selective conscription allows governments to incur more battlefield deaths during war because it breaks the direct link from casualties to political sanctions.

We test this theoretical framework two ways. First, we introduce a new dataset that provides complete coverage of conscription policies for each belligerent country in every international conflict from 1800 to 2015, manually coded from historical and archival sources. We demonstrate that countries with selective conscription suffer approximately 13,000 more battlefield deaths on average — nearly triple the baseline rate-compared to countries with all-volunteer or universal conscription policies. Further, consistent with our theoretical argument, these differences are more pronounced among countries that initiate conflicts, and this higher tolerance for casualties also correlates with shorter wars and a higher probability of victory.

Second, we then examine whether our theoretical mechanism—selective conscription shielding politically-valuable citizens from battlefield deaths-explains these broad patterns. We leverage an in-depth quantitative case study of the United States' experience during the Vietnam conflict, introducing another novel dataset linking archival records of all Vietnam-era casualties from the US Department of Defense to soldiers' home counties. After the introduction of universal conscription via the lottery in late 1969 , the government lost the ability to protect electorally valuable voters from the human cost of the war. Using a difference-in-differences design, we show both that the US shifted to a war strategy that led to a sudden, sharp decline in casualties, and that the deaths became more equally distributed: deaths in electorally uncompetitive counties were $32 \%$ higher than those in competitive counties under selective conscription, but declined much faster after the introduction of the lottery, until casualty rates became equal irrespective of countywide voting patterns.

This paper makes at least two important contributions to the study of conscription and warfare. While previous research has explored the effects of military labor acquisition on battlefield performance (Horowitz, Simpson, and Stam 2011; Vasquez 2005), it has not connected this relationship to governments' political exposure. We provide the first evidence of linking conscription systems to politicians' expectations about how casualties will impact their political fortunes through 
the mechanism of determining military strategy. These findings resonate with an emerging literature on how domestic political incentives at the micro level affect the ways in which wars are fought (Davis 2021). For example, Lyall (2020) describes how ethnic and socioeconomic inequalities reduce troop cohesion and degrade battlefield performance. Similarly, we show that elites' political incentives to distribute the burden of military service unequally can also generate more battlefield deaths.

We also go beyond previous studies in distinguishing between universal and selective conscription. While many scholars have examined the differences between volunteer and conscripted militaries (Annaka et al. 2019; Asal, Conrad, and Toronto 2017; Choi and James 2003, 2008; Cohn and Toronto 2017; Margulies 2018; Pickering 2011), ours is the first to identify the critical distinction between universal and selective conscription. We show that the latter is unique in allowing politicians to shield politically valuable constituencies from battlefield deaths, which generates military strategies that are less constrained by domestic politics than under alternative conscription systems. Our findings suggest that future research on domestic politics and battlefield performance should disaggregate universal and selective conscription.

\section{The Domestic Politics of Conscription}

Politicians governing countries at war typically have two objectives: win the war and stay in power. These goals are often at cross purposes (Croco 2011; Debs and Goemans 2010; Weeks 2012). Winning usually requires governments to spend money, take strategic risks, and absorb casualties, yet the high costs of war can erode the government's support among both the public and elite networks. Asking supporters to pay too high a price for victory can leave the government vulnerable to replacement (Cotton 1986; Escribà-Folch 2013; Geys 2010). Democratic governments that fail to balance these objectives may lose re-election; in nondemocracies, they can instead be overthrown, with former leaders ousted, exiled, or killed (Goemans 2000).

Politicians may wish to solve this conundrum by spreading the costs of war strategically, placing 
the greatest burden on those whose support is immaterial to their hold on power. But many costs cannot be targeted in this way: labor dislocations, food shortages, commodity supply disruptions, and other disturbances to daily life are shared burdens (Carter 2017; Glick and Taylor 2008; Goldin and Lewis 1975). Taxes offer one means of focusing the economic cost of war on selected citizens; governments can also offer targeted incentives for contributing to the war effort, such as vouchers and, for businesses, military contracts (Bueno de Mesquita et al. 2003; Rockoff 2012).

The greatest price of any war, however, are the human costs paid on the battlefield. When soldiers die in combat, the communities from which they are drawn experience short- and long-term psychological, social, and economic disruption (Angrist 1990; Cesur, Sabia, and Tekin 2013; Hansen and Weisbrod 1967; Tanielian and Jaycox 2008; Kriner and Shen 2010, 2020). These effects are typically localized; for example, Kriner and Shen (2007) find that the death of an American soldier is borne by their home county to a much greater extent than it is by their state or the country as a whole (see also, e.g., Althaus, Bramlett, and Gimpel 2012). For politicians looking to ensure that winning a war does not cost them their office, recruiting military labor from communities which are less politically valuable is an attractive means of strategically distributing the cost of war. ${ }^{2}$

Conscription systems-which we define as the set of policies and procedures by which governments raise militaries-determine governments' ability to shield politically important segments of society from the costs of the battlefield. All countries have military labor acquisition systems that fall roughly into three categories: all-volunteer military service, universal conscription, and selective conscription (Toronto and Cohn 2020). Countries with all-volunteer militaries rely exclusively upon citizens to enlist voluntarily, while universal conscription systems require all male adults to serve. Under selective conscription systems, governments compel only certain groups of citizens to enlist, for example those of certain political parties or ethnic backgrounds. ${ }^{3}$

All-volunteer militaries do not typically allow politicians to shield politically valuable communities

2. We note that we are agnostic about whether this strategy actually inures politicians against the risk of replacement, or whether politicians merely perceive it to do so.

3. For our purposes, restricting conscription by sex or by age (as in the United States' Selective Service System) does not make conscription "selective." In the context of our data, spanning every country from 1800 to 2015 , women and children are virtually always exempted from conscription, so coding this condition as "selective" would mask the variation in other selective conscription policies which are the focus of our theoretical argument. 
from service. Because the government cannot compel its citizens to serve, it must instead compete in the labor market by offering incentives such as attractive pay structures, benefits packages, and quality of life perks. This competition makes such forces more expensive to recruit and maintain (Asch et al. 2010; Mulligan and Shleifer 2005). Volunteers who die are also more costly to replace, which rules out riskier military strategies which the government may otherwise wish to pursue (Horowitz, Simpson, and Stam 2011). For example, the American military has been an all-volunteer force since the end of the Vietnam War. ${ }^{4}$ Relatively few soldiers have died in the war in Afghanistan, ${ }^{5}$ but because the military cannot commit hundreds of thousands of troops to exert control over the entire country (Kolenda 2019), major US objectives such as eradicating the Taliban remain elusive. For countries fighting wars like the US in Afghanistan, the combination of relying on broad economic incentives to recruit troops and the reluctance to suffer significant casualties constrain the government's ability to selectively limit battlefield deaths among certain groups.

Even less flexibility is afforded politicians fighting a war with a military that is dependent upon universal conscription. By design, universal conscription spreads the cost of service more or less evenly across society, whether it is truly universal (i.e., everyone is conscripted) or citizens are chosen randomly via a lottery. By design, universal conscription does not allow a government to shield its supporters from military service because conscripts are drawn from politically valuable constituencies at the same rate as they are from less valuable constituencies. ${ }^{6}$ Examples of countries employing universal conscription include Lithuania and South Korea, both of which face close, hostile neighbors that seriously threaten their territorial integrity.

In stark contrast are countries with selective conscription systems. In such contexts governments can compel citizens to fight, ensuring an ample supply of soldiers, while at the same time allowing them the flexibility to choose who serves. Specific provisions that indicate selective conscription include discretionary conscription (i.e., arbitrarily waving the requirement to serve), as well as

4. The Selective Service System remains in law, but in a dormant state, and the last conscription occurred in 1973.

5. At time of writing, approximately 2,500 soldiers have died in Afghanistan, or 5\% of the total casualties suffered in Vietnam over the same period.

6. While governments may provide exemptions and deferments, these are typically narrowly designed to protect wartime industrial capacity, and in practice the vast majority of male citizens must serve in the military. 
outright statutory favoritism. For example, in North Korea, all male citizens are required to serve except for the children of the political and military elite, as well as those whose political loyalty is considered questionable (Worden 2008). In a less extreme example, during World War I, the United Kingdom excluded Ireland (then part of the UK) from conscription to appease Irish nationalists (Adams and Poirier 1987). Similarly, in World War II, the Canadian government exempted French-Canadians from conscription in an effort to stave off broader political conflict over the place for French speakers in a predominantly English-speaking military (Byers 2016). Elsewhere, policies may superficially look similar to those under universal conscription (e.g., granting deferments), but are routinely and asymmetrically abused to favor particular groups, such that conscription is de facto selective. For example, many countries have excluded politically important occupations from service despite their having only tangential connection to the war effort (Fennell 2019). France's 1793 levée en masse, the first universal conscription, changed to a selective system just 7 years later when Napoleon's Consulate began allowing citizens to buy themselves out of military service, effectively exempting the landed aristocracy (Poutvaara and Wagener 2009). Similar policies have been embedded in military labor procurement in the United States during the Civil War, the former Soviet Union, and modern China and Russia.

The key feature of selective conscription systems is that they allow politicians to enact military labor recruitment policies that broadly protect politically important groups from military service. By limiting conscription according to, for example, ideology, occupation, or social class, governments can shield these groups—-who may be core supporters or "swing" voters, depending on context—from the human cost of the war. Because combat deaths will be disproportionately drawn from communities which are less important for their political survival, politicians have more latitude in balancing the risk of losing power against their desire to win the war. They will be more willing to pursue risky, casualty-intensive warfare strategies in pursuit of victory because the threat of replacement is not as strong. All else equal, we therefore expect that countries with selective conscription systems will experience more battlefield deaths during war than countries with all-volunteer or universally-conscripted militaries. 
Of course, conscription systems do not spontaneously materialize; the choice of conscription system is itself often politically motivated (Flynn 1998; Jehn and Selden 2002; Mulligan and Shleifer 2005). For example, Australian Prime Minister William Morris Hughes attempted to institute universal conscription through normal legislation; when he could not muster a majority to pass it, he put it to a referendum in 1916, and then again in 1917. Both measures failed. Levi (1996, 154) ascribes Australia's choice to stick with an all-volunteer military at the height of World War I to "a combination of antistatism, prolabor sympathies, and distrust of the Hughes government to implement conscription fairly." Such cases are common, but we nevertheless argue that conscription systems are (for our purposes) "quasi-parameters" (Greif and Laitin 2004): institutions that, while amenable to change over the long run, are typically fixed in the short term. Once a decision to go to war has been taken, a country's extant military institutions will, to a large extent, determine the the way that the war is fought. For the purpose of our cross-national analysis, we therefore take conscription systems as fixed. ${ }^{7}$

We note that this argument is agnostic about regime type: we expect these patterns to hold in democracies and nondemocracies alike. To be sure, there are important differences across regime types in how conscription systems are designed and implemented (Levi 1996), how wars are fought (Reiter and Stam 1998a), and how politicians are sanctioned for poor performance on the battlefield (Reiter and Stam 1998b). Yet we argue the mechanism underlying our theoretical argument operates across the full spectrum of democracy. For example, a British Prime Minister may fear only a vote of no confidence or the loss of re-election if battlefield casualties rise beyond what the party or public will tolerate. In contrast, war may leave a North Korean dictator vulnerable to a military coup if casualties erode support among the top brass. We expect that selective conscription diminishes the threat of both types of sanction because it disproportionately protects politically valuable groups from experiencing battlefield deaths.

7. Among the 575 observations in our data, only 6 are countries that have switched conscription systems mid-war: the United Kingdom during World War I, Germany and the Soviet Union during World War II, China and North Korea during the Korean War, and the US during Vietnam. Our results are robust to alternative codings of these cases, as well as excluding them from the analysis (see the online appendix). 


\section{Data and Method}

Our main theoretical claim is that selective conscription leads to more casualties during war because it allows politicians to choose military strategies without as much fear of domestic backlash against battlefield deaths. To test this argument, we first gathered data on our independent variable of interest, conscription systems. Using archival and historical sources, we coded each country's conscription scheme as either all-volunteer, universal conscription, or selective conscription for each year from 1800 to $2015 .^{8}$ Because our argument centers on who actually bears the human cost of the war and the political implications thereof, we focus on de facto conscription systems. This approach also allows us to readily distinguish universal conscription with standardized deferments from selective conscription with policies that look similar but function instead as politicized disbursement of exemptions from service.

We coded militaries as all-volunteer if they did not rely upon conscription in any form. Consistent with our decision to use de facto military labor recruitment policies, we coded countries as all-volunteer even when they had legal or bureaucratic mechanisms for conscription but did not use them (as in the United States since 1975). Countries that require all young men to engage in military service were coded as having universal conscription systems, whether they truly enlist every eligible citizen or instead rely on a random lottery of would-be conscripts, as the two have the same effect on the demographic makeup of the military. All other military labor acquisition systems were coded as selective conscription, of which there are many varieties due to politicians' attempts to shield specific populations from the battlefield. This trichotomous coding scheme necessarily simplifies diverse conscription policies into a few large categories, and the line between universal and selective systems can be blurry. Consistent with our theoretical argument, our primary criterion for distinguishing the two is whether exemptions, disbursements, and other policies function in practice to generate routine disparities in military service for essentially political ends, like in the examples given above. We note that coding a country as having either universal or selective conscription does not imply that their forces exclude all volunteers; all militaries rely to some extent

8. See the online appendix for a list of data sources. 
on volunteers, who in conscription systems, typically make up the officer corps (Mulligan and Shleifer 2005). In our final dataset, $43 \%$ of the cases are countries with all-volunteer forces, $26 \%$ have universal conscription, and $31 \%$ have selective conscription.

For our dependent variable, battlefield deaths, we use Project Mars data covering all wars fought between conventional armies from 1800 to 2011 (Lyall 2020). Deaths are expressed as a count of the number of soldiers killed in action (KIA) per country, per war. Only deaths that occurred on the battlefield are included; soldiers who went missing or died of illness are not counted toward the total. ${ }^{9}$ We note that these data only include combatants recognized as countries, with non-state belligerents excluded. However, this selection rule does not threaten our analysis because non-state actors rarely have the capacity to organize and implement conscription systems.

We regress deaths on conscription system using a standard negative binomial generalized linear model. Due to the structure of our dependent variable, our unit of analysis is the country-war. For example, separate observations capture France in World War I, France in World War II, and Germany in World War II. Our data are not dyads but rather statements of the characteristics of each country and its participation in a particular conflict. Since countries can engage in overlapping conflicts, our data are formally cross-sectional rather than a panel. ${ }^{10}$

Conscription systems do not determine battlefield deaths alone. Because aggressors may be willing to suffer greater casualties (Slantchev 2004), we control for whether the country initiated the war. A long tradition in democratic peace theory suggests that democracies are less likely to fight wars against each other, and particularly wars with heavy casualties (Gleditsch 1992). We therefore control for whether the country is a democracy, as well as whether the country's opponent is a democracy, each coded as at least a seven on the Polity IV scale (Marshall, Jaggers, and Gurr 2011). Since casualties are a function of the magnitude of the conflict, we also include a measure of total number of troops deployed at the outset of the war. To capture the extent of a country's relative

9. Since battlefield deaths can often be difficult to identify and categorize, Project Mars reports both high and low estimates. We use the lower bound estimate in the main analysis, but our results are robust to using the upper bound estimate instead (see the online appendix).

10. Although it is possible to construct time-series cross-sectional data, battlefield deaths are not sufficiently temporally disaggregated to allow for distinct observations by country-year. See the appendix for estimates from a model where we distribute deaths evenly across country-war-years, which are substantively identical to our main results. 
(dis)advantage in a conflict, we also include a measure of the number of troops deployed by the country as a proportion of the total number of troops deployed, both measured at the start of the conflict. Following the convention in the literature, we include a dummy variable for whether the country-war is part of either World War, given the extreme casualties suffered during each. Finally, we expect casualties to be lower for countries further apart and for shorter wars, so we include the logged distance between belligerents (in kilometers) and the logged duration (in days) of the conflict. Table 1 provides summary statistics for the dependent variable and control variables. ${ }^{11}$

\section{The Effect of Conscription Systems on Warfare}

Figure 1 provides our main result. Predicted battlefield deaths per country-war are plotted by conscription system with dots, with lines for $95 \%$ confidence intervals. Countries with all-volunteer forces and universal conscription are both expected to experience approximately 7,400 deaths per war. In contrast, countries with selective conscription are predicted to experience over 20,400 deaths per war, nearly triple the rate of deaths under alternative conscription systems. These differences are substantively large and statistically significant. They are also robust to adding country fixed effects to our model (see the online appendix for full regression results). Consistent with our theoretical

Table 1: Summary statistics, global conscription data

\begin{tabular}{lrrrrr}
\hline Statistic & Min. & Median & Mean & Max. & St. Dev. \\
\hline KIA (1,000s) & 0.00 & 1.50 & 57.68 & $11,000.00$ & 529.45 \\
Initiator & 0.00 & 0.00 & 0.43 & 1.00 & 0.50 \\
Democracy & 0.00 & 0.00 & 0.19 & 1.00 & 0.39 \\
Democratic Opponent & 0.00 & 0.00 & 0.15 & 1.00 & 0.35 \\
Total Deployed (1,000s) & 0.03 & 60.00 & 418.23 & $34,476.70$ & $1,945.49$ \\
Relative Power & 0.00 & 0.35 & 0.37 & 0.96 & 0.25 \\
World War & 0.00 & 0.00 & 0.17 & 1.00 & 0.38 \\
Distance (logged) & 0.00 & 6.73 & 6.58 & 9.73 & 1.81 \\
Duration (logged) & 0.00 & 5.43 & 5.20 & 9.17 & 1.75 \\
\hline
\end{tabular}

"KIA" refers to the number of soldiers killed in action.

11. All control variables are provided in the Project Mars data. 


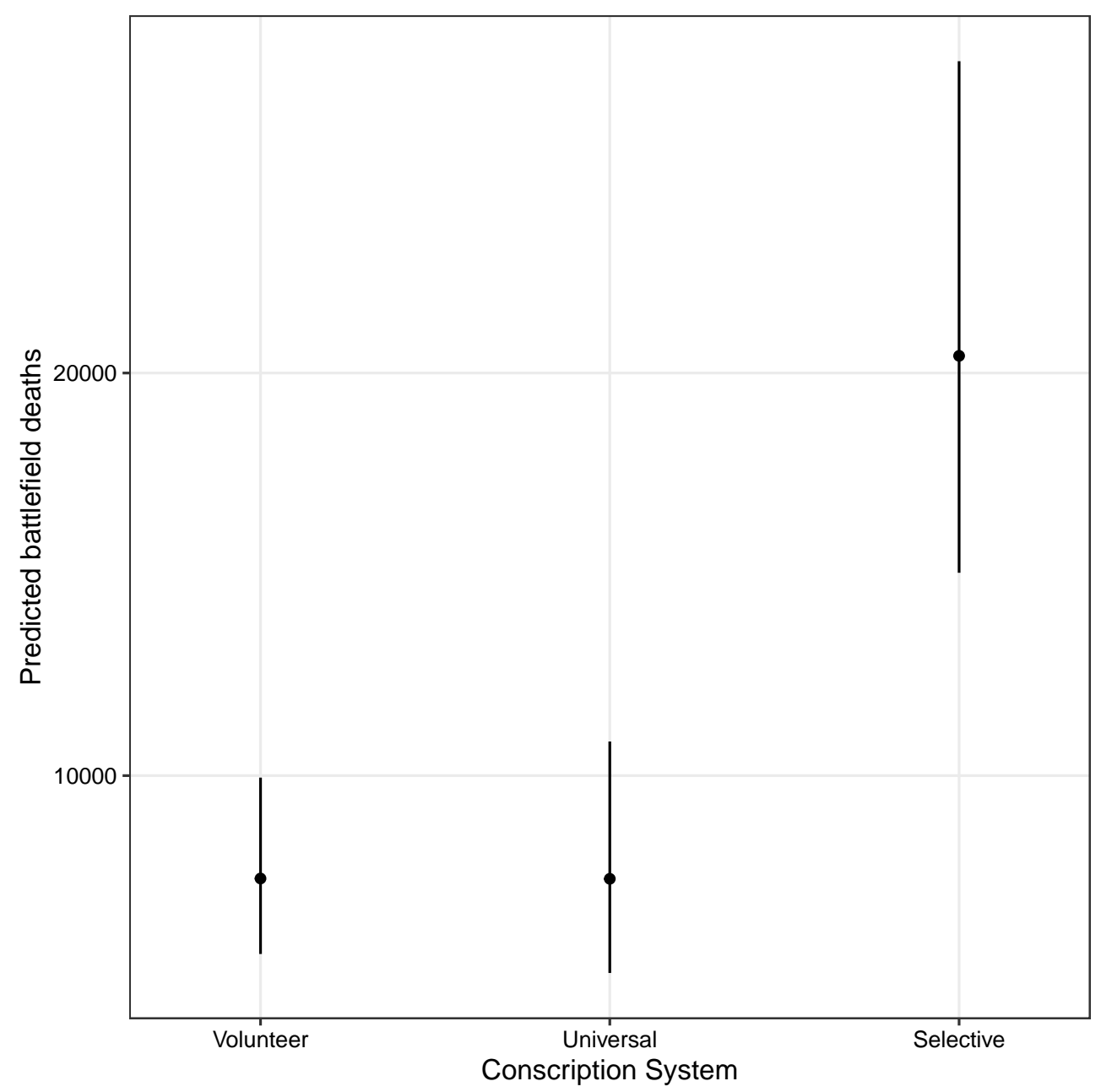

Figure 1: Predicted battlefield deaths by conscription system. Dots indicate estimates, with lines for $95 \%$ confidence intervals, from our main model. See the online appendix for full regression results.

argument, selective conscription correlates with more battlefield deaths than those experienced under other conscription systems.

Countries that initiate wars are often more willing to experience battlefield deaths. Our results could be explained by the alternative explanation that countries with selective conscription are just more likely to start a war and suffer more casualties as a result. To test for this possibility, we regress initiator status on conscription type and the other control variables. In results reported in the online appendix, we find no effect of selective conscription on the probability a country initiates war.

To further probe this question, we re-estimate our main model but interact initiator status with 

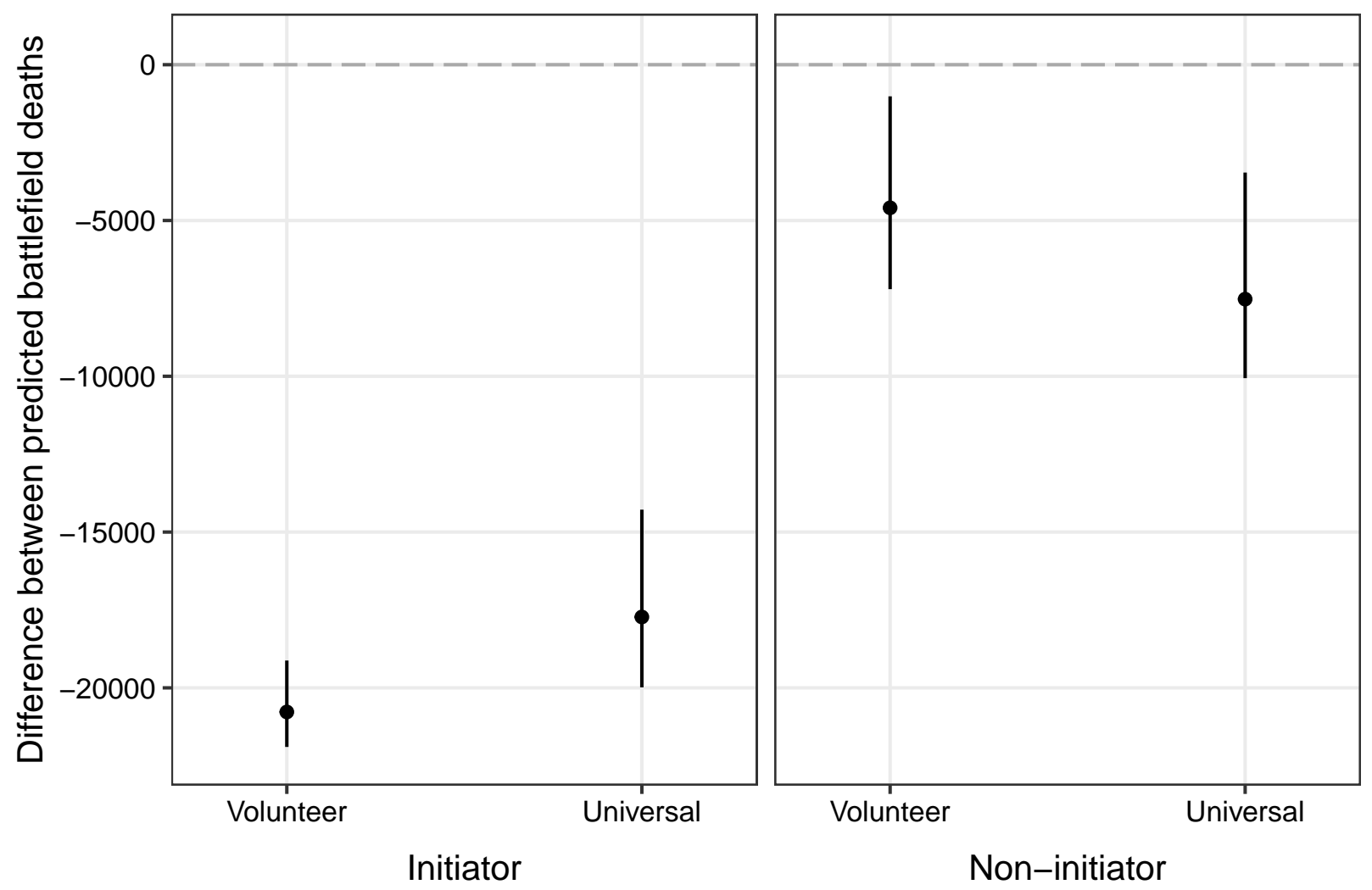

Figure 2: Predicted difference between battlefield deaths under selective conscription and alternative systems, by initiator status. Dots indicate estimates, with lines for $95 \%$ confidence intervals, from a model interacting conscription system and initiator. See the online appendix for full regression results.

conscription system. The difference between predicted battlefield deaths under selective versus alternative conscription systems are plotted in Figure 2. Among countries that initiate the war, our main effect is even larger than in our baseline model: selective conscription is associated with 18,000-21,000 extra casualties compared to all-volunteer or universal conscription militaries. The effect sizes are smaller among non-initiators, at 5,000-8,000 more deaths, but selective conscription is still associated with significantly more deaths. These patterns are consistent with our theoretical framework: they suggest that countries with selective conscription are always more likely to suffer casualties, and that these differences are exaggerated when countries choose to go to war.

It is also possible that our results are driven primarily by older observations and anachronistic warfare strategies. To examine this possibility, we subset our data to only those wars occurring after World War I, following the literature's standard definition of the "modern era" of war (Lyall 2020). 
Re-estimating our main model yields substantively unchanged results (see the online appendix), and although the smaller sample size leads to more uncertainty, selective conscription is still statistically significantly associated with more deaths—-still on the order of double those observed under alternative conscription systems.

The results so far support our argument. However, we can go further by digging into additional implications of our theoretical framework. In particular, we expect that battlefield deaths will be higher in countries with selective conscription because they will be freer to pursue riskier and more casualty-heavy military strategies. With this heavier price comes a notable upside: the possibility that this strategic freedom allows commanders to take actions that improve their country's odds of winning and hasten the end of the war. Our theoretical argument suggests that selective conscription should therefore be associated with a greater probability of victory and shorter wars.

We manually code victory as a binary outcome using secondary sources (Kohn 2006), then regress it on conscription system and the same controls as in our main model. Although there appears to be no difference between countries with selective conscription and all-volunteer forces, both are significantly more likely to win than countries with universal conscription: roughly $50 \%$ compared to $35 \%$, respectively. To examine war duration, we regress our duration variable on conscription systems and the remaining controls. As expected, wars fought by countries with selective conscription are predicted to last 170 days, compared to 204 days for universal conscription and 248 days for all-volunteer forces. ${ }^{12}$

Taken together, these results provide robust evidence in support of our theoretical framework. As expected, countries with selective conscription experience more battlefield deaths, particularly when they initiate war, are more likely to win the wars they fight, and tend to fight shorter wars. However, all of this evidence is cross-sectional and correlational, and so cannot speak to causal relationships. To better understand whether the mechanism we propose - that selective conscription breaks the link from battlefield deaths to political sanction-can explain these patterns, we need finer-grained data. For this we turn to America's experience in Vietnam.

12. See the full results reported in the online appendix. 


\section{America in the Vietnam War}

"Vietnam is getting worse every day. I have the choice to go in with great casualty lists or to get out with disgrace. It's like being in an airplane and I have to choose between crashing the plane or jumping out. I do not have a parachute." ${ }^{13}$ By the summer of 1965, after ten years and 2,000 US casualties, President Lyndon Johnson had a decision to make: should he escalate American involvement in Vietnam and risk thousands more deaths in pursuit of victory, or should he withdraw and suffer public opinion backlash, jeopardizing his Democratic party's majorities in both houses of Congress? His aeronautical simile summarized the essential dilemma facing leaders of countries at war: balancing the desire to win with the desire to remain in power. As is now known to history, Johnson chose escalation, to disastrous effect. Battlefield deaths quadrupled from 1965 to 1966 and doubled again from 1966 to 1967 . By the time the US withdrew in defeat in 1975, some 58,000 American soldiers had died. ${ }^{14}$

The United States' intervention in Vietnam provides a unique opportunity to explore the mechanisms of our theoretical argument. America's selective conscription system had long provided for the nation's military labor needs, but in ways that generated enormous class- and race-based inequities (Appy 1993; Kriner and Shen 2010). Fourteen years into the conflict, the US transitioned to a universal, lottery-based conscription system that was designed to reduce these disparities. This policy shift makes America in the Vietnam War one of just six cases where we can examine the difference between two different conscription systems in the same country during the same conflict.

\section{Historical Context}

Upon the surrender of Japan's occupying forces at the end of World War II, the Vietnamese emperor abdicated the throne. Communist leader Ho Chi Minh declared a Democratic Republic of Vietnam in Hanoi (North Vietnam); France, the former colonial power in the region, responded by

13. These remarks were recorded on July 8, 1965, by his wife, Lady Bird Johnson.

14. Between 1 and 3 million Vietnamese (mostly civilians) are estimated to have died during the conflict, which was just one of four wars Vietnam fought during the first four decades of independence. We focus on the US perspective because our goal is to examine the effects of a change in conscription system mid-war. 
declaring a republic based in Saigon (South Vietnam). As intermittent fighting broke out in both countries, Soviet, Chinese, and British troops arrived to support their respective allies, escalating the conflict - the First Indochina War-into a Cold War proxy front. Following eight years of war, the 1954 Geneva Accords temporarily divided Vietnam at the 17th parallel. Elections and a subsequent reunification of Vietnam were scheduled for 1956, but in 1955 the South held its own elections and declared itself an independent republic, restarting the conflict that would continue until American withdrawal and the fall of South Vietnam in 1975.

President Harry Truman had sent military advisors to Vietnam as early as 1950 to support the French in South Vietnam. By 1955, France had decided its position in Vietnam was no longer tenable, and agreed for American aid and military technical advisors to be directed to the South Vietnamese government. The US began sending military advisors by the hundreds in 1961, and in 1964, under the pretext of having been attacked first, conducted large-scale retaliatory airstrikes against North Vietnamese insurgents. What had been a technical group of 2,000 advisors in 1961 grew to 20,000 troops when US Marines landed in Da Nang in March 1965, beginning the American ground offensive. By December-five months after Johnson realized he "had no parachute"—over 200,000 US soldiers were stationed in Vietnam (for an overview see Tucker 2011).

These soldiers were mostly conscripted through a decentralized process administered by the Selective Service System (SSS). Established in 1940 as an independent agency under the direct control of the president (subject to congressional oversight), the SSS was organized into local draft boards. The director of the SSS was granted substantial discretion to determine the number of enlistments needed, which were then disaggregated and passed to the boards, who were in turn given wide latitude with both quotas and methods used to achieve them. This organization gave the president significant influence over who served in the military and in what capacity. The president's control over conscription was bolstered further by discretionary authority to create $a d$ hoc deferments, which were used extensively (Flynn 1993): in the 35 years from its foundation through the end of the Vietnam War, the SSS exempted far more men from service than it conscripted (Baskir and Strauss 1978). 
Because the SSS was organized to give the president significant discretion over conscription, it was, from inception, a political beast. Citizens, policymakers, powerbrokers, donors, and politicians lobbied the SSS for deferments, exemptions, and selective enforcement of quotas, often for political ends such as maximizing their favored candidates' re-election prospects. Knowing Congress and the president had the power to shape the future of the SSS, administrators were especially responsive to overtures from members of Congress and White House officials. Like other bureaucracies under political control (Keiser, Mueser, and Choi 2004; Keiser and Soss 1998; Weingast and Moran 1983), the discretion afforded the SSS allowed it to pursue the political goals of those who oversaw it.

Politically-motivated selective conscription generated enormous inequities. For example, from 1950-1966, $22 \%$ of white conscripts failed the mandatory physical examination, compared to only $15 \%$ of Black conscripts. A civilian analyst in the Surgeon General's Office cited "greater sophistication" of middle-class white men "with regard to the medical standards for deferment" as a key cause of this disparity (Supplement to Health of the Army 1969, 17). Contemporaries connected the greater burden on Black men with their lack of representation on draft boards: in 1966, only $1.3 \%$ of all draft board members were Black, 23 states had no Black draft board members at all, and in only one state was Black representation proportional to the Black population (Murray 1971).

The political origins of these inequities did not go unnoticed by the public and contributed to an already growing distaste for the Vietnam conflict. Protests swelled and members of Congress began to speak out against the war. The Johnson administration sought a public reckoning over its prosecution of the war, and in 1967, empaneled a public commission on the selective conscription system. The resulting report castigated the SSS for gross inefficiencies and numerous geography-, class-, and race-based inequities (National Advisory Commission on Selective Service 1967). After the election of President Richard Nixon in 1968, and ten months of no change in the prosecution of the war, anti-Vietnam sentiment reached its peak. Under intense public pressure, Nixon decided to implement universal conscription via a centralized lottery system (Flynn 1993).

The conversion from a decentralized selective conscription system with little oversight to a centralized universal conscription system via random lottery effectively ended the political 
manipulation of military labor acquisition. With very few exceptions, interest groups could no longer obtain deferments for their industries, members of Congress could no longer protect their constituencies, and officials in local, state, and national draft boards could no longer uniltaterally grant deferments or set exemption policies by fiat. On December 1st, 1969, the first random draw selected men born on 14 September with the initial "J," and men with initials JJJ were all but certain to serve. Successive lotteries were held again in 1970, 1971, and 1972, fulfilling America's military labor needs for the remainder of the Vietnam War.

\section{Estimation Strategy}

At a macro level, our theoretical framework implies that following the shift in conscription system we should see a switch from a casualty-intensive warfare strategy to one that did not risk as many soldiers, and that battlefield deaths would subsequently decline. Digging deeper into the micro-level mechanism, we expect to find evidence of politically valuable constituencies being shielded from the human cost of the war under selective conscription, but no such differences after the lottery was introduced. We argue that, in the context of America's electoral democracy during the Vietnam War era, the most valuable constituencies were "swing" districts that collectively alternated between voting for Democrats and Republicans. While scholars of distributive politics disagree about whether parties target core or swing voters in general (Dixit and Londregan 1996; Lindbeck and Weibull 1987), the comparatively low polarization in mid-20th century America suggests an environment where winning persuadable voters paid the largest electoral dividends (e.g., in the landslide victories of 1936, 1964, 1972, 1980, and 1984). We therefore predict that deaths through December 1969 were disproportionately drawn from less electorally competitive counties, while deaths thereafter were evenly distributed irrespective of countywide voting patterns.

To test these hypotheses, we gather data on every American casualty in Vietnam (National Archives 2008). These records include every soldier who died in Vietnam (and neighboring countries) from 1956 to 1975, providing such information as their: address of record, date of birth, religion, race, and marital status; service details, including military branch, rank, unit, and pay 
Table 2: American deaths during the Vietnam War, 1956-1975

\begin{tabular}{lcc} 
& $\mathrm{N}$ & $\%$ \\
\hline Type of death: & & \\
KIA & 47,103 & 81.72 \\
Other & 10,539 & 18.28 \\
\hline Type of service: & & \\
Drafted & 17,447 & 30.27 \\
Regular & 34,183 & 59.30 \\
Reserve & 5,834 & 10.12 \\
\hline Race: & & \\
White & 49,708 & 86.24 \\
Black & 7,228 & 12.54 \\
Other & 706 & 1.22 \\
\hline Counts and percentages may not sum to \\
57,642 and 100\% (respectively) due to \\
missingness.
\end{tabular}

grade; and circumstances of death, including date, location, and cause. This information allows us to match each casualty to the county where the soldier registered his or her service. We exclude soldiers who resided outside the 50 US states and the District of Columbia, as well as those that occurred after the war's end, were entered in error, or had no known address. We then aggregate the remaining 57,642 deaths, summarized in Table 2, by county-year.

We match these data to county-level census data provided by the Census Bureau (Haines 2010). Because population data are gathered only once every ten years, we geometrically interpolate missing years, then divide by 1,000 to ease interpretation. We merge these data with county-level results from the 1952, 1956, 1960, 1964, 1968, and 1972 presidential elections (Clubb, Flanigan, and Zingale 1987), then truncate to examine only 1956-1975. Our unit of observation is the county-year, so our data comprise a balanced panel of 3,163 US counties across twenty years.

We estimate a difference-in-differences model. Our treatment is whether a county is electorally competitive, which we define as counties where the two-party vote share differential between Democrats and Republicans in the most recent presidential election is less than ten percentage points. We interact this with our time variable, which is coded as a 0 for years the US used the selective 
conscription system (1956-1969) and 1 for the years after the lottery was introduced (1970-1975). ${ }^{15}$ If the mechanism we theorize holds water, then we should see: more deaths across all counties before the lottery; more deaths in uncompetitive counties than competitive counties before the lottery; and an equal number of deaths across competitive and uncompetitive counties after the lottery was introduced.

\section{Results}

Results from our main model are plotted in Figure 3. We find all three pieces of evidence to support our theoretical mechanism. Deaths significantly decline after the introduction of the lottery-on average, from about 1.09 soldiers per county-year to just 0.49 . Before the lottery, these deaths were concentrated in less politically valuable counties. Uncompetitive counties experienced 1.21 deaths between 1956 and 1969, 32\% higher than competitive counties' 0.91 deaths. These differences evaporated after the introduction of universal conscription, and if anything, competitive counties experienced more deaths ( 0.47 compared to 0.42 in uncompetitive counties).

Quantifying the net effect on total deaths implied by these estimates is difficult because it is impossible to predict what Presidents Eisenhower, Kennedy, and Johnson would have done under alternative conscription systems. If we extrapolate the death rate in the post-lottery period backward across the entire Vietnam War, then we expect the United States would have suffered approximately 26,400 fewer casualties. Alternatively, we could assume the overall warfare strategy would have remained the same throughout the war, but without a conscription system that protected politically valuable counties, so that the distribution of pre-lottery deaths would have been more equal. In this counterfactual scenario, if the death rate among competitive counties equaled that of uncompetitive counties before 1970, we expect the US would have suffered nearly 2,200 more battlefield deaths.

There are at least two important threats to inference for which our analysis must account. Most

15. We interpret results below without fixed effects, but our results remain statistically significant and are substantively unchanged with them included (see the online appendix). We note that we include county fixed effects but are unable to include year fixed effects because these are linear combinations of the time variable. Instead, we include interpolated male population to account for within-county changes to the draft-eligible population over time. 


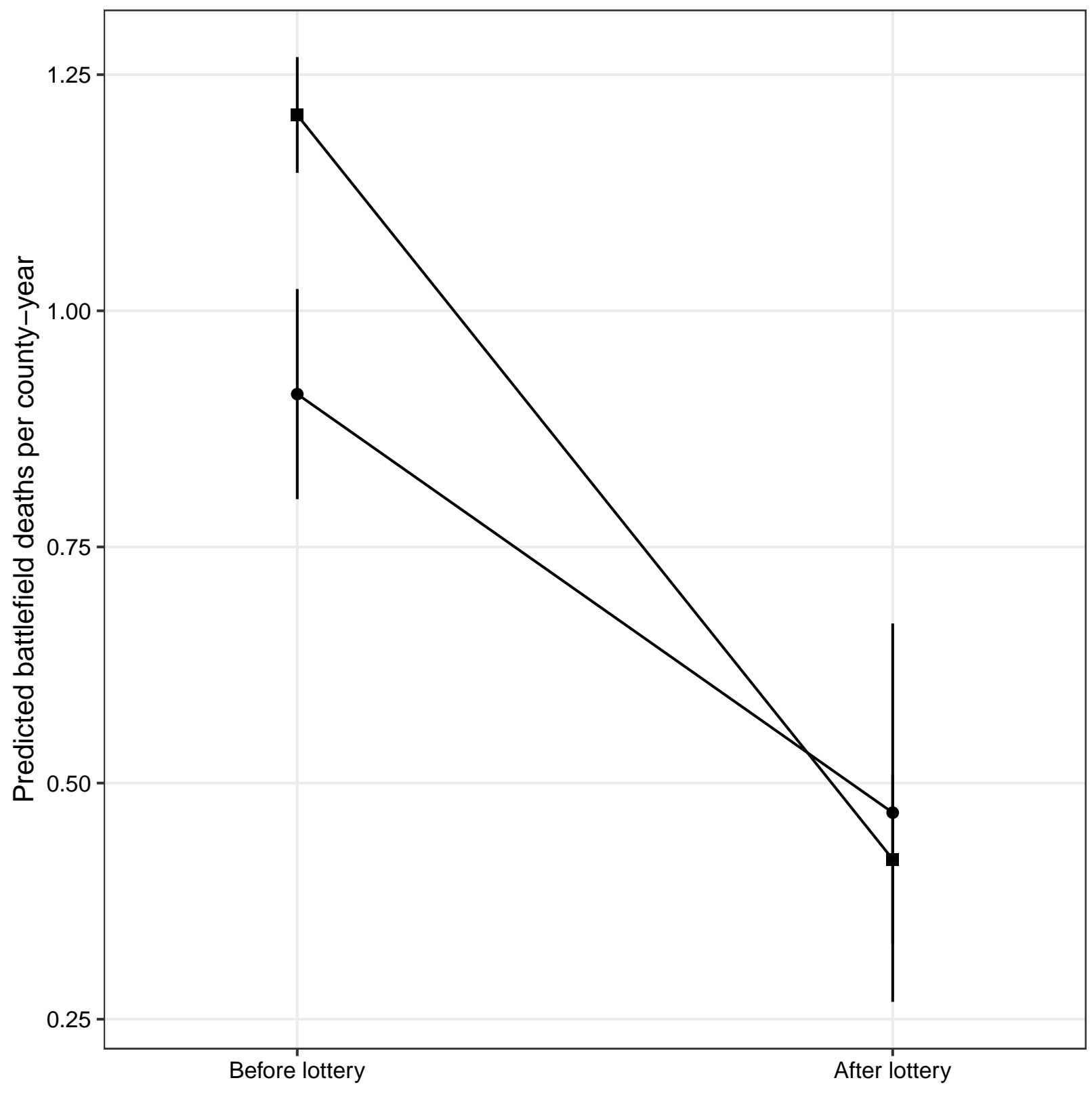

Figure 3: Predicted battlefield deaths of soldiers from competitive counties (in circles) and uncompetitive counties (squares) before and after the introduction of the lottery, with lines for $95 \%$ confidence intervals.

notable is that we do not have data on military service at the county level. All else equal, counties with more soldiers will have higher death rates even after normalizing for population, so if the data-generating process for soldiers is correlated with presidential vote share, then our results are likely to be unreliable. To account for this possibility, we re-estimate our main model while restricting attention to deaths of only those soldiers who were drafted, since draftees should be 
more closely correlated to the county population than volunteers. In results reported in the online appendix, we show that the estimates from this model are nearly identical. Even after parceling out the potentially endogenous reasons for enlistment, selective conscription still appears to protect draftees from electorally competitive counties.

The second threat to inference comes from the fact that we do not directly observe the mechanism—politicized decisions made by draft boards and SSS officials. While it is possible that an alternative mechanism exists, it would require that, conditional on being sent into battle, mortality rates were correlated with home county electoral competitiveness. We see no reason to expect that soldiers from swing counties would be more skilled than those from other counties, nor any reason to expect that enemy forces would have been able to deliberately target soldiers from electorally competitive districts, so the probability of death should be as-if random among soldiers fighting alongside each other. Thus, the only means of preventing deaths of soldiers from politically valuable counties is to protect them from being sent to battle in the first place- the mechanism at the heart of our theoretical argument.

\section{Selective Conscription and Warfare}

In this paper, we argue that conscription systems mediate the relationship between domestic political incentives and warfare strategy. Battlefield casualties can threaten incumbents' political survival, but selective conscription gives politicians more flexibility to determine who fights, granting them more flexibility to pursue risky, casualty-intensive warfare strategies.

Using new data on conscription systems worldwide, we have shown that countries with selective conscription experience more battlefield deaths during war, especially (but not only) when initiating conflict, and are therefore able to fight shorter wars that they are more likely to win. Zooming in on America's experience during the Vietnam War, we find strong support for the mechanism we propose: politically valuable counties were shielded from battlefield deaths until the end of selective conscription in 1969, after which deaths were distributed across counties irrespective of 
voting patterns. Taken together, these results provide substantial evidence that selective conscription shapes warfare strategy by structuring politicans' domestic political incentives.

Our findings point to a number of avenues for future research. For one, we demonstrate that selective conscription decreases politicians' sensitivity to the domestic political risks generated by battlefield deaths, but selective conscription is itself a very broad category, and it is unclear what variation among selective conscription systems matters. We discussed examples of exemptions from service - including those based on nationality, language, occupation, economic class, family ties to the ruling regime, and political ideology — as well as specific exemption mechanisms, including deferments and fitness-to-serve determinations. Yet we cannot speak to the trade-offs politicians face in carving out these selection procedures. As the American experience in Vietnam shows, too much selection may itself lead to a growing sense of unfairness which backfires and leaves politicians more sensitive to public backlash than they might have been under a more equitable conscription system. Future research may examine this dynamic relationship between public support and specific selective conscription policies, which is beyond the scope of this paper.

Further, because mid-war changes to conscription systems are so rare, we have taken conscription systems as largely fixed. Yet clearly military labor acquisition policies shift over time, often for political reasons (Mulligan and Shleifer 2005). Scholars working on conscription systems and warfare may want to take a long view of these relationships by examining their endogenous evolution with changing domestic political landscapes. It may be that focusing on politicians' fear of replacement during one war may shed new light on how they rebuild conscription systems for future wars, and therefore how warfare evolves over time.

Finally, our data indicate that, conditional on fighting a war, countries with selective conscription are no more likely to have been the initiator than countries with alternative conscription systems. However, the unconditional probability of how likely politicians are to fight wars under different conscription systems remains an open question. There are good reasons to believe that all-volunteer forces may increase hawkishness among both voters and politicians in the US (e.g., Horowitz and Levendusky 2011), but there is little cross-national evidence on this question. Further, scholars have 
found that public support for war varies by such contextual factors as international backing, domestic elite consensus, and the objective of military action (Johns and Davies 2012). Conscription systems may be particularly important for mediating the relationship between support for war and military strategy for some wars, but not for others. Our data provide scholars new opportunities to investigate these important questions in the study of domestic politics and war. 


\section{References}

Adams, R. J. Q., and Philip P. Poirier. 1987. The Conscription Controversy in Great Britain, 1900-18. Columbus, $\mathrm{OH}$ : Ohio State University Press.

Althaus, Scott L., Brittany H. Bramlett, and James G. Gimpel. 2012. "When War Hits Home: The Geography of Military Losses and Support for War in Time and Space." Journal of Conflict Resolution 56 (3): 382-412.

Angrist, Joshua D. 1990. "Lifetime Earnings and the Vietnam Era Draft Lottery: Evidence from Social Security Administrative Records.” American Economic Review 80 (3): 313-336.

Annaka, Susumu, Munenori Kita, Naonari Yajima, and Rui Asano. 2019. Democracy, Conscription, and War: The Effects of Political Regimes and Types of Military Recruiting on the Initiation of Militarized Interstate Disputes. Paper presented at the 2019 annual meeting of the Japan Association for Comparative Politics.

Appy, Christian G. 1993. Working-Class War: American Combat Soldiers and Vietnam. Chapel Hill: University of North Carolina Press.

Asal, Victor, Justin Conrad, and Nathan Toronto. 2017. "I Want You! The Determinants of Military Conscription.” Journal of Conflict Resolution 61 (7): 1456-1481.

Asch, Beth J., Paul Heaton, James Hosek, Francisco Martorell, Curtis Simon, and John T. Warner. 2010. Cash Incentives and Military Enlistment, Attrition, and Reenlistment. National Defense Research Institute monograph.

Baskir, Lawrence M., and William A. Strauss. 1978. Chance and Circumstance: The Draft, the War, and the Vietnam Generation. New York: Alfred A. Knopf.

Berinsky, Adam J. 2009. In Time of War: Understanding American Public Opinion from World War II to Iraq. Chicago: University of Chicago Press.

Bueno de Mesquita, Bruce, Alastair Smith, Randolph M. Siverson, and James D. Morrow. 2003. The Logic of Political Survival. Cambridge, MA: MIT Press.

Byers, Daniel Thomas. 2016. Zombie Army: The Canadian Army and Conscription in the Second World War. Vancouver: University of British Columbia Press.

Carter, Jeff. 2017. "The Political Cost of War Mobilization in Democracies and Dictatorships." Journal of Conflict Resolution 61 (8): 1768-1794.

Cesur, Resul, Joseph J. Sabia, and Erdal Tekin. 2013. "The Psychological Costs of War: Military Combat and Mental Health.” Journal of Health Economics 32 (1): 51-65.

Choi, Seung-Whan, and Patrick James. 2003. "No Professional Soldiers, No Militarized Interstate Disputes? A New Question for Neo-Kantianism." Journal of Conflict Resolution 47 (6): 796-816.

- 2008. "Civil-Military Structure, Political Communication, and the Democratic Peace." Journal of Peace Research 45 (1): 37-53. 
Clubb, Jerome M., William H. Flanigan, and Nancy H. Zingale. 1987. Electoral Data for Counties in the United States: Presidential and Congressional Races, 1840-1972. Ann Arbor, MI: Inter-university Consortium for Political and Social Research [distributor]. https://doi.org/10.3886/ICPSR08611.v1.

Cohn, Lindsay P., and Nathan W. Toronto. 2017. "Markets and Manpower: The Political Economy of Compulsory Military Service." Armed Forces \& Society 43 (3): 436-458.

Cotton, Timothy Y. C. 1986. "War and American Democracy: Electoral Costs of the Last Five Wars." Journal of Conflict Resolution 30 (4): 616-635.

Croco, Sarah E. 2011. “The Decider's Dilemma: Leader Culpability, War Outcomes, and Domestic Punishment." American Political Science Review 105 (3): 457-477.

Davis, Jason Sanwalka. 2021. "War as a Redistributive Problem.” American Journal of Political Science.

Debs, Alexandre, and Hein E. Goemans. 2010. "Regime Type, the Fate of Leaders, and War." American Political Science Review 104 (3): 430-445.

Dixit, Avinash, and John Londregan. 1996. "The Determinants of Success of Special Interests in Redistributive Politics.” Journal of Politics 58 (4): 1132-1155.

Escribà-Folch, Abel. 2013. "Accountable for What? Regime Types, Performance, and the Fate of Outgoing Dictators, 1946-2004.” Democratization 20 (1): 160-185.

Fennell, Jonathan. 2019. Fighting the People's War: The British and Commonwealth Armies and the Second World War. Cambridge: Cambridge University Press.

Flynn, George Q. 1993. The Draft, 1940-1973. Lawrence, KS: University of Kansas Press.

-. 1998. "Conscription and Equity in Western Democracies, 1940-75." Journal of Contemporary History 33 (1): 5-20.

Gartner, Scott Sigmund, and Gary M. Segura. 1998. "War, Casualties, and Public Opinion.” Journal of Conflict Resolution 42 (3): 278-300.

Gelpi, Christopher, Peter D. Feaver, and Jason Reifler. 2009. Paying the Human Costs of War: American Public Opinion and Casualties in Military Conflicts. Princeton, NJ: Princeton University Press.

Geys, Benny. 2010. "Wars, Presidents, and Popularity: The Political Cost(s) of War Re-Examined." Public Opinion Quarterly 74 (2): 357-374.

Gleditsch, Nils Petter. 1992. "Democracy and Peace.” Journal of Peace Research 29 (4): 369-376.

Glick, Reuven, and Alan M. Taylor. 2008. Collateral Damage: Trade Disruption and the Economic Impact of War. National Bureau of Economic Research (NBER) Working Paper No. 11565.

Goemans, Hein E. 2000. "Fighting for Survival: The Fate of Leaders and the Duration of War." Journal of Conflict Resolution 44 (5): 555-579. 
Goldin, Claudia D., and Frank D. Lewis. 1975. "The Economic Cost of the American Civil War: Estimates and Implications." The Journal of Economic History 35 (2): 299-326.

Greif, Avner, and David D. Laitin. 2004. “A Theory of Endogenous Institutional Change.” American Political Science Review 98 (4): 633-652.

Grose, Christian R., and Bruce I. Oppenheimer. 2007. "The Iraq War, Partisanship, and Candidate Attributes: Variation in Partisan Swing in the 2006 U.S. House Elections." Legislative Studies Quarterly 32 (4): 531-557.

Haines, Michael R. 2010. Historical, Demographic, Economic, and Social Data: The United States, 1790-2002. Ann Arbor, MI: Inter-university Consortium for Political and Social Research [distributor]. https://doi.org/10.3886/ICPSR02896.v3.

Hansen, W. Lee, and Burton A. Weisbrod. 1967. "Economics of the Military Draft." Quarterly Journal of Economics 81 (3): 395-421.

Horowitz, Michael C., and Matthew S. Levendusky. 2011. "Drafting Support for War: Conscription and Mass Support for Warfare.” Journal of Politics 73 (2): 524-534.

Horowitz, Michael C., Erin M. Simpson, and Allan C. Stam III. 2011. "Domestic Institutions and Wartime Casualties.” International Studies Quarterly 55 (4): 909-936.

Jehn, Christopher, and Zachary Selden. 2002. "The End of Conscription in Europe?" Contemporary Economic Policy 20 (2): 93-100.

Johns, Robert, and Graeme A. M. Davies. 2012. "Democratic Peace or Clash of Civilizations? Target States and Support for War in Britain and the United States." Journal of Politics 74 (4): $1038-1052$.

Keiser, Lael R., Peter R. Mueser, and Seung-Whan Choi. 2004. "Race, Bureaucratic Discretion, and the Implementation of Welfare Reform." American Journal of Political Science 48 (2): 314-327.

Keiser, Lael R., and Joe Soss. 1998. "With Good Cause: Bureaucratic Discretion and the Politics of Child Support Enforcement.” American Journal of Political Science 42 (4): 1133-1156.

Kohn, George C. 2006. Dictionary of Wars. New York: Checkmark Publishing.

Kolenda, Christopher D. 2019. "Slow Failure: Understanding America's Quagmire in Afghanistan." Journal of Strategic Studies 42 (7): 992-1014.

Kriner, Douglas L., and Francis X. Shen. 2007. "Iraq Casualties and the 2006 Senate Elections." Legislative Studies Quarterly 32 (4): 507-530.

- 2010. The Casualty Gap: The Causes and Consequences of American Wartime Inequalities. New York: Oxford University Press.

- 2020. "Battlefield Casualties and Ballot-Box Defeat: Did the Bush-Obama Wars Cost Clinton the White House?" PS: Political Science \& Politics 53 (2): 248-252.

Levi, Margaret. 1996. “The Institution of Conscription.” Social Science History 20 (1): 133-167. 
Lindbeck, Assar, and Jorgen Weibull. 1987. "Balanced Budget Redistribution as the Outcome of Political Competition.” Public Choice 52 (3): 273-297.

Lyall, Jason. 2020. Divided Armies: Inequality and Battlefield Performance in Modern War. Princeton, NJ: Princeton University Press.

Margulies, Max Z. 2018. "Patrons and Personnel: The Determinants of Military Recruitment Policies.” PhD diss., University of Pennsylvania.

Marshall, Monty G., Keith Jaggers, and Ted Robert Gurr. 2011. "Polity IV Project.” Center for Systemic Peace.

McMahon, Robert. 2002. "Contested Memory: The Vietnam War and American Society, 1975-2001." Diplomatic History 26 (2): 159-184.

Mueller, John E. 1973. War, Presidents, and Public Opinion. New York: Wiley.

Mulligan, Casey B., and Andrei Shleifer. 2005. "Conscription as Regulation." American Law and Economics Review 7 (1): 85-111.

Murray, Paul T. 1971. "Blacks and the Draft: A History of Institutional Racism." Journal of Black Studies 2 (1): 57-76.

National Advisory Commission on Selective Service. 1967. In Pursuit of Equity: Who Serves When Not All Serve? Report of the National Advisory Commission on Selective Service.

National Archives. 2008. U.S. Military Casualties, Missing in Action, and Prisoners of War from the Era of the Vietnam War. Vietnam Conflict Extract Data File. National Archives Identifier 2240992. Available at https://www . archives.gov/research/military/vietnamwar/electronic-records.html. Last accessed 15 June 2021.

Pickering, Jeffrey. 2011. "Dangerous Drafts? A Time-Series, Cross-National Analysis of Conscription and the Use of Military Force, 1946-2001." Armed Forces \& Society 37 (1): 119-140.

Poutvaara, Panu, and Andreas Wagener. 2009. The Political Economy of Conscription. Institute for the Study of Labor (IZA) Discussion Paper No. 4429.

Reiter, Dan, and Allan C. Stam III. 1998a. "Democracy and Battlefield Military Effectiveness." Journal of Conflict Resolution 42 (3): 259-277.

- 1998b. "Democracy, War Initiation, and Victory." American Political Science Review 92 (2): 377-389.

Rockoff, Hugh. 2012. America's Economic Way of War: War and the U.S. Economy from the Spanish-American War to the First Gulf War. New York: Cambridge University Press.

Slantchev, Branislav L. 2004. "How Initiators End Their Wars: The Duration of Warfare and the Terms of Peace.” American Journal of Political Science 48 (4): 813-829.

Supplement to Health of the Army. 1969. Supplement to Health of the Army: Results of the Examination of Youths for Military Service, 1968. Washington: Medical Statistics Agency, Office of the Surgeon General. 
Tanielian, Terri, and Lisa H. Jaycox, eds. 2008. Invisible Wounds of War: Psychological and Cognitive Injuries, Their Consequences, and Services to Assist Recovery. Santa Monica, CA: Rand Corporation.

Toronto, Nathan W., and Lindsay P. Cohn. 2020. "Conscription and the Politics of Military Recruitment.” In Oxford Research Encyclopedia of Politics. Oxford: Oxford University Press.

Tucker, Spencer C., ed. 2011. The Encyclopedia of the Vietnam War: A Political, Social, and Military History. 2nd edition. Santa Barbara, CA: ABC-CLIO.

Vasquez, Joseph Paul, III. 2005. "Shouldering the Soldiering: Democracy, Conscription, and Military Casualties." Journal of Conflict Resolution 49 (6): 849-873.

Weeks, Jessica L. 2012. "Strongmen and Straw Men: Authoritarian Regimes and the Initiation of International Conflict." American Political Science Review 106 (2): 326-347.

Weingast, Barry R., and Mark J. Moran. 1983. "Bureaucratic Discretion or Congressional Control? Regulatory Policymaking by the Federal Trade Commission." Journal of Political Economy 91 (5): 765-800.

Worden, Robert L., ed. 2008. North Korea: A Country Study. 5th edition. Washington, DC: Federal Research Division, Library of Congress. 